\title{
Study of the Effect of Changes on the Technological and Physical-Mechanical Properties of Knitting in a New Structure
}

\author{
Shahboz Shokirjonugli Shogofurov, Iroda Ibrohimovna Kamalova, \\ Kurbonali Madaminovich Xolikov
}

Faculty of Technology of Light Industry, Namangan Institute of Engineering and Technology, Namangan, Uzbekistan

Email: shogofurov@mail.ru, kamalovairoda09@gmail.com, qurbonalixoliqov@gmail.com

How to cite this paper: Shogofurov, S.S., Kamalova, I.I. and Xolikov, K.M. (2021) Study of the Effect of Changes on the Technological and Physical-Mechanical Properties of Knitting in a New Structure. Engineering, 13, 287-299.

https://doi.org/10.4236/eng.2021.136021

Received: May 7, 2021

Accepted: June 21, 2021

Published: June 24, 2021

Copyright $\odot 2021$ by author(s) and Scientific Research Publishing Inc. This work is licensed under the Creative Commons Attribution International License (CC BY 4.0).

http://creativecommons.org/licenses/by/4.0/

\begin{abstract}
In this article, we compared four types of knitted fabrics with high two-ply shape retention. Experimental samples of a two-layer knitted fabric have been developed and graphic symbols have been applied on a flat-needle weaving machine of the 12th class LONG-XING SM 252 (China).
\end{abstract}

\section{Keywords}

Knitwear, Double Knit, Hoop, Yarn, Flat, Dimensional Lightness, Hoop Height, Surface Density, Pattern, Density, Hoop Strip Length, Polyacrylonitrile

\section{Introduction}

Today there is a great demand for patterned knitted fabrics, which are distinguished by their appearance inside the knitted fabrics. Therefore, the market is ready to expand the range of products that have a beautiful appearance, good shape, physical and mechanical and hygienic properties, low cost of raw materials, but high quality. This allows you to reduce the cost of modernization and replacement of new equipment [1] [2]. The desired results are achieved by obtaining knitted fabrics with new properties on the basis of basic and derivative fabrics of knitted fabrics by adding additional elements to them or by changing the production process. A method of weaving two single-ply knitted fabrics at the same time on a flat needle machine is known. For the different trajectories of the machine, the method of dividing two sets of needles into groups and placing the base and connecting threads on each group of needles using a thread guide according to the number of needle groups is the most optimal method in terms 
of technical solution for knitting [3] [4]. In this case, in a single pass of the carriage, the threads passed through the needles on the opposite side, and the threads placed on the machine needles through the thread guide, respectively, from the loop rows of knitting. It is necessary to take into account the fact that knitted fabrics are obtained on the basis of basic and derivative fabrics by adding additional elements to them or by changing the production process to acquire new features of knitted fabrics [5] [6].

\section{Methods}

In this research work, the technological potential of the 12th class LONG-XING SM 252 flat fang knitting machine was studied, and a new mixed pattern knitted fabric was created on the basis of elastic fabric, using $35 \times 2$ textile polyacrylic nitrile yarn as a raw material. Technological parameters and physical and mechanical properties of knitted fabrics of the new structure were studied [7].

Graphic records of samples of elastic $1+1$ knitted fabric made of polyacrylonitrile raw material are given in the 1st variant of the knitted fabric with high shape retention properties. Due to the fact that the elastic fabric belongs to the category of head tissues, it is accepted as a basic fabric. In Versions 2 and 3, due to the tight insertion of additional press rings on the back side of the fabric, embossed patterns were formed on the front side, which in turn further improved the properties of the knitwear (Figure 1). The weaving method of Versions 2 and 3 is the same, but due to the change in the density of the horizontal and vertical, the size of the embossed patterns on the surface of the knitwear has changed significantly, so these fabrics are mechanically and technically separate.

In Version 4, the smooth side of the knit fabric is combined with the front openwork rings with elastic bands to create a patterned pattern, which in turn improves the shape and reduces the elongation and reduces the elongation. Indicators and characteristics were determined experimentally. The technological parameters of knitted fabrics determined experimentally are given in Table 1.

It is known how to weave two layers of knitwear at the same time on a flat needle machine. This method does not ensure the stability of the loop angle when passing through the thread, which in turn indicates the need to move the needle locks relative to each other. In addition, this method does not allow to simultaneously join the two tissues in the contour, which is a significant drawback.

Table 1. Technological parameters of tissues.

\begin{tabular}{ccccccccccc}
\hline Versions & $\begin{array}{c}\text { The composition } \\
\text { of the yarn } \\
\text { in the fabric, \% }\end{array}$ & $\begin{array}{c}\text { Ring pitch, } \\
\mathrm{A}(\mathrm{mm})\end{array}$ & $\begin{array}{c}\text { Ring row } \\
\text { height, } \\
\mathrm{V}(\mathrm{mm})\end{array}$ & $\begin{array}{c}\text { Horizontal } \\
\text { density, } \mathrm{P}_{\mathrm{h},}\end{array}$ & $\begin{array}{c}\text { Vertical } \\
\text { density, } \mathrm{P}_{\mathrm{v},}\end{array}$ & $\begin{array}{c}\text { The length of } \\
\text { the ring strip, } \\
\mathrm{L}(\mathrm{mm})\end{array}$ & $\begin{array}{c}\text { Surface } \\
\text { density } \\
\mathrm{m}_{\mathrm{rp}}\left(\mathrm{g} / \mathrm{m}^{2}\right)\end{array}$ & $\begin{array}{c}\text { Thickness, } \\
\mathrm{M}(\mathrm{mm})\end{array}$ & $\begin{array}{c}\text { Dimensional } \\
\text { density, } \\
\delta\left(\mathrm{mg} / \mathrm{cm}^{3}\right)\end{array}$ \\
\hline 1 & & 1.39 & 0.83 & 36 & 60 & 3.8 & 459.6 & 3.4 & 135 \\
2 & & 1.42 & 1.11 & 35 & 45 & 4 & 355.4 & 4.35 & 81.7 \\
3 & PAN 35/2 & 1.66 & 0.86 & 30 & 58 & 4.3 & 419.7 & 4.2 & 99.93 \\
4 & & 1.47 & 1.04 & 34 & 48 & 4.5 & 415.2 & 3.68 & 112.8 \\
\hline
\end{tabular}




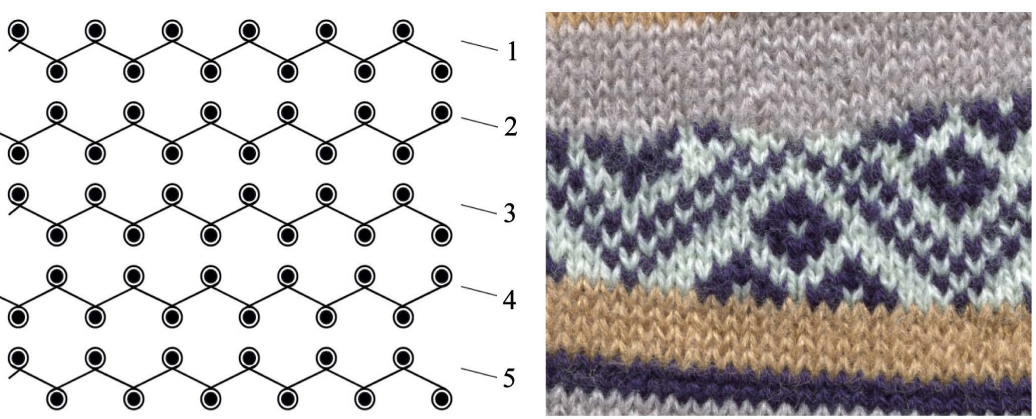

Version I
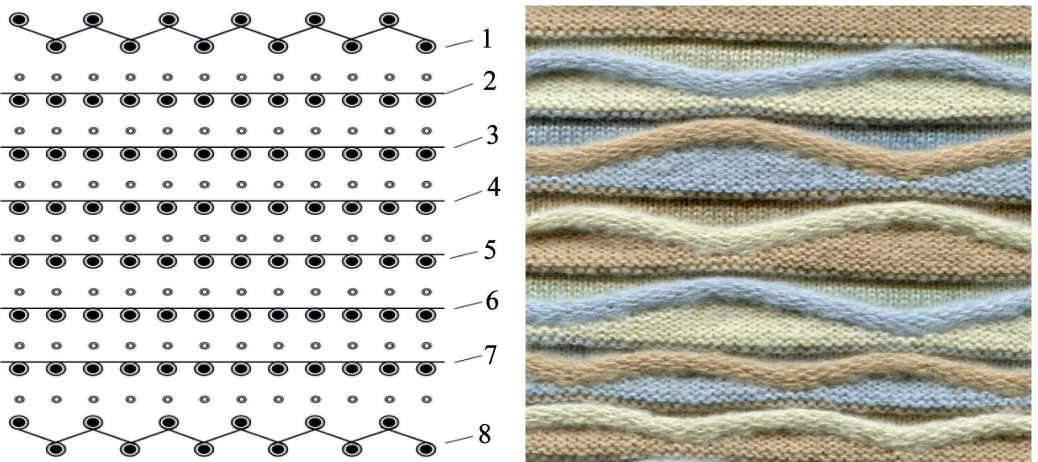

Version II
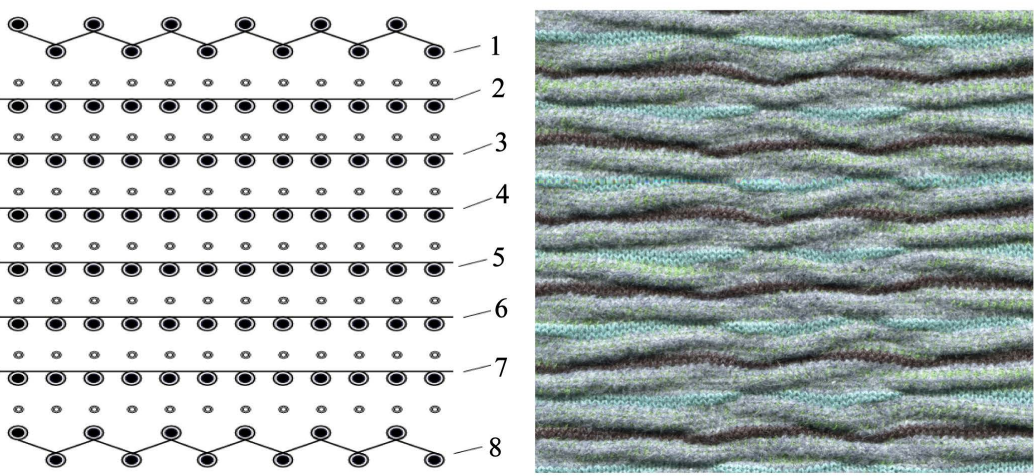
Version III
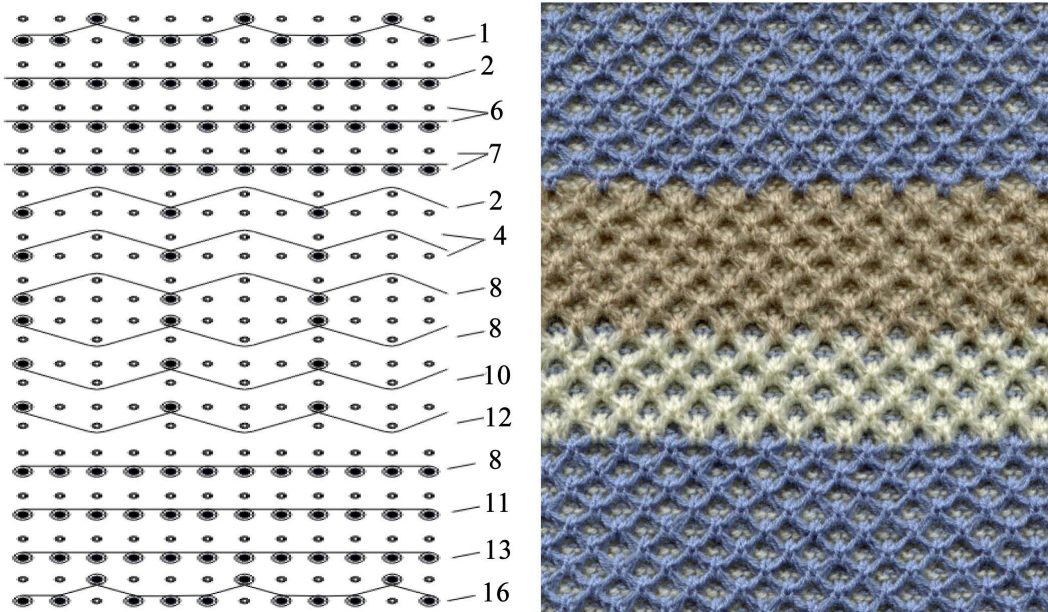

Version IV

Figure 1. Structure and graphic writing of patterned mixed knitted fabrics. 
The method of splitting two sets of needles into groups for different trajectories on a flat-needle machine and placing the base and connecting threads on each group of needles with the help of a thread guide according to the number of needles, is the technique of knitting. In this case, the yarn is passed through the set of needles on the opposite side of the carriage once, and the threads, which are inserted into the set of needles through the thread guide, form a loop of knitwear. Version 1 of the 3 versions listed in the table is the base fabric, which is the tire texture on a two-needle flat fang machine. Version 2 and Version 3 are new knitted fabric patterns that have achieved new variants of mixed knitted fabrics by adding glad, press and openwork rings to the rubber fabric base. The raw material composition in the tissue was the same and was developed using $\mathrm{Nm}=28.6 / 2(35 \times 2$ tex $)$ polyacrylonitrile yarn.

\section{Discussions}

Technological parameters such as ring pitch $A(\mathrm{~mm})$, ring row height $\mathrm{V}(\mathrm{mm})$, horizontal density $\mathrm{P}_{\mathrm{H}}$, vertical density $\mathrm{P}_{\mathrm{V}}$, ring strip length $\mathrm{L}(\mathrm{mm})$, surface density mgr, thickness $\mathrm{M}$, volume density $\delta$ were determined experimentally, is included in Table 1. If the results are analyzed, the ring step (Figure 2) from the earliest technological indicators of knitted fabric increased by $2 \%-19 \%$ in all variants in relation to the base fabric: rubber. The height of the ring row appears to have increased in the range of $4 \%-34 \%$ on the options relative to the base fabric. The next indicator is the thickness of the tissue. In order to further determine the raw material used for knitted fabric, its thickness should also be taken into account. The thickness of the samples can also be determined under laboratory conditions on a special thickness measuring instrument (YG141D). It is observed that the thickness of the tissue increased by $29 \%$ in terms of variants relative to the base tissue.

If the tissue thickness is observed, in Version 1 is $3.4 \mathrm{~mm}$, in Version 4 is 3.7 $\mathrm{mm}$, in Version 3 is $4.2 \mathrm{~mm}$, and in Version 2 is $4.4 \mathrm{~mm}$. If these values are

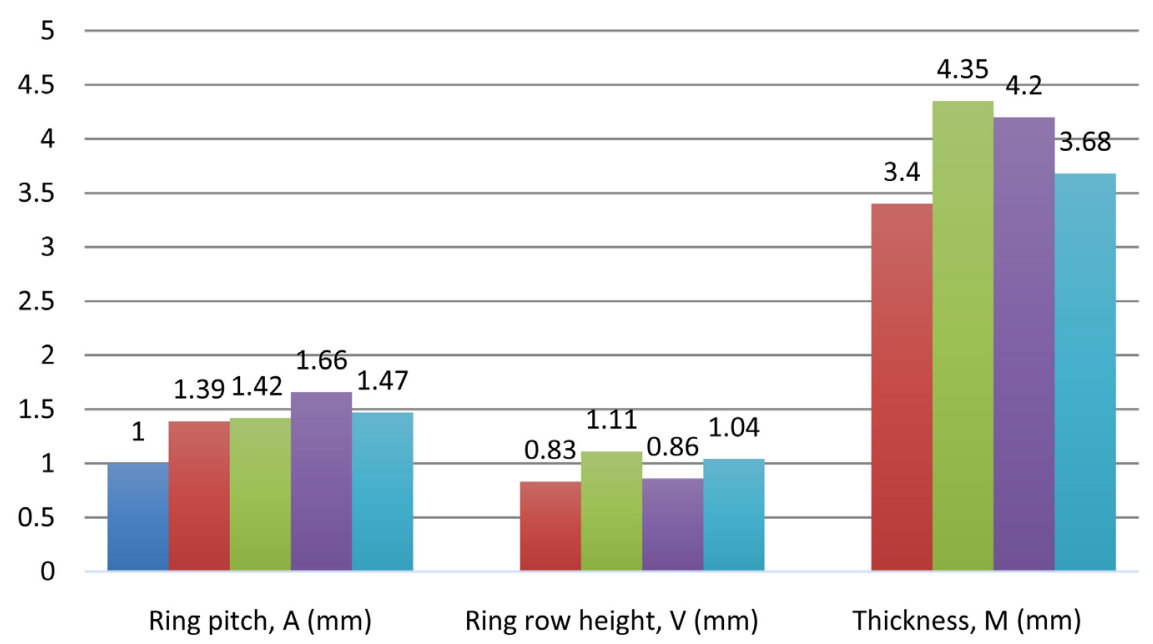

Figure 2. Ring pitch, ring row height and thickness change diagram. 
expressed as a percentage, the thickness increased by $9 \%-29 \%$ relative to Version 1 (Figure 2). If the change in the length of the ring strip is directly due to the effect of the press and openwork rings included in the fabric composition, it directly affects the surface density of the fabric and leads to an increase in this figure. The indicators of the length of the loop strip in the fabric are as follows: we can see that the remaining options are elongated relative to the base fabric (Figure 3).

The next indicator on the table is the density on the horizontal $\left(\mathrm{R}_{\mathrm{H}}\right)$, the density on the vertical $\left(\mathrm{R}_{\mathrm{V}}\right)$. In the underlying tissue, the horizontal density $\left(\mathrm{R}_{\mathrm{H}}\right)$ consists of 36 rings and the vertical density $\left(\mathrm{R}_{\mathrm{V}}\right)$ consists of 60 rings. In all variants, the horizontal density $\left(\mathrm{R}_{\mathrm{G}}\right)$ consists of $30-35$ loops, which appear to be reduced by $3 \%-20 \%$ relative to the underlying tissue (Figure 4 ). In the variants, the vertical density $\left(R_{V}\right)$ consists of $48-58$ rings and it is reduced by $4 \%-25 \%$ relative to the base tissue.

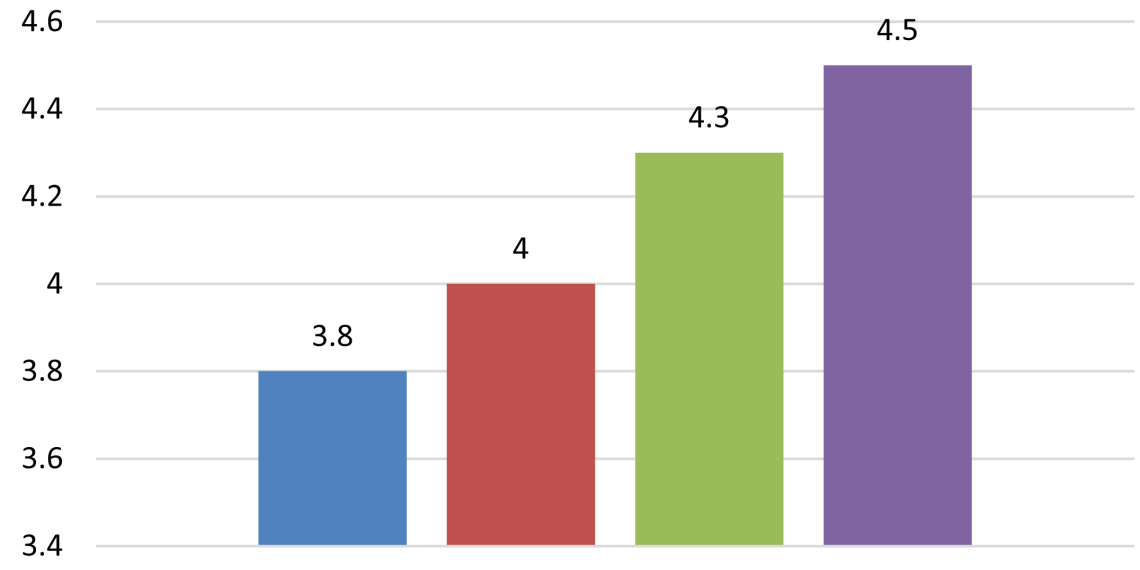

The length of the ring strip, $L(\mathrm{~mm})$

Figure 3. Diagram of the change in the length of the loop of tissue.

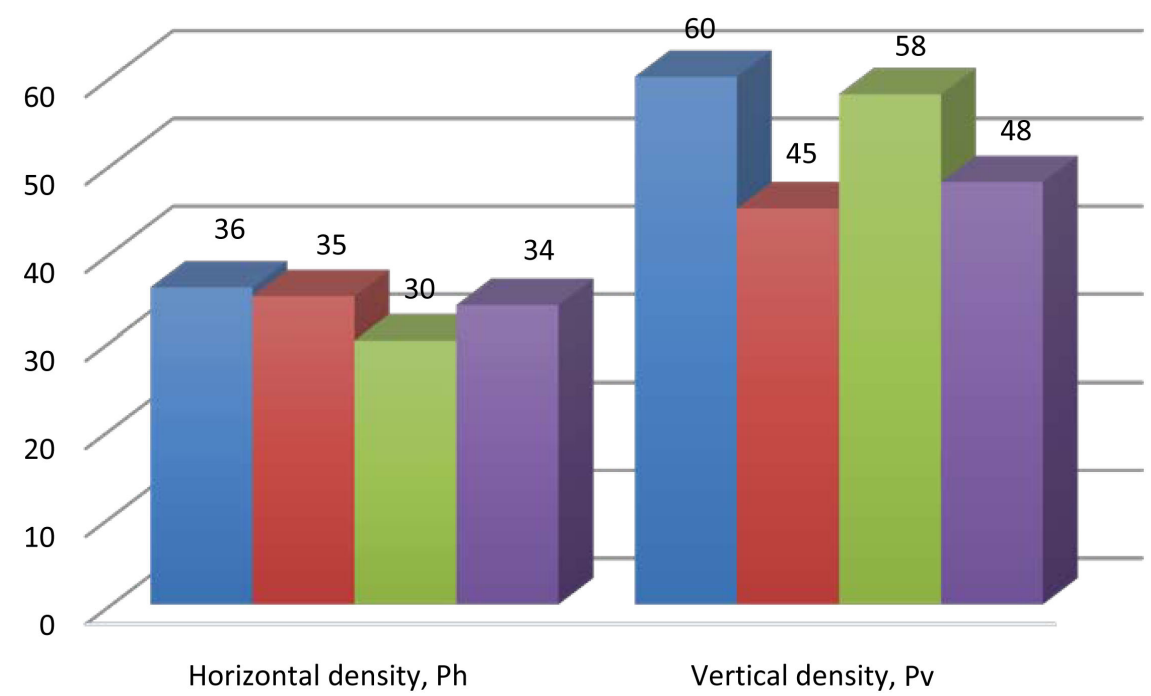

Figure 4. Diagram of the change of densities in the horizontal and vertical. 
Since the surface density is directly related to the raw material consumption and the volume density is related to the tissue thickness, it is correct to estimate by this indicator (Figure 5). The volumetric density of a two-layer base knitted fabric (Version I) with a surface density of $\mathrm{Ms}=459.6 \mathrm{~g} / \mathrm{m}^{2}$ and a thickness of $\mathrm{T}$ $=3.4 \mathrm{~mm}$ is $135 \mathrm{mg} / \mathrm{cm}^{3}$, the volumetric density of the knitted fabric (Version II) with a surface density of $\mathrm{Ms}=355.4 \mathrm{~g} / \mathrm{m}^{2}$ and a thickness of $\mathrm{T}=4.35 \mathrm{~mm}$ was $81.7 \mathrm{mg} / \mathrm{cm}^{3}$.

The volumetric density of the knitted fabric in variant with a surface density of Ms $=419.7 \mathrm{~g} / \mathrm{m}^{2}$ and a thickness of $\mathrm{t}=4.2 \mathrm{~mm}$ is $99.93 \mathrm{mg} / \mathrm{cm}^{3}$, and the volumetric density of the basic knitted fabric (Version I) is equal to $135 \mathrm{mg} / \mathrm{cm}^{3}$ (Figure 5).

The surface density of Version IV knitwear was $415.2 \mathrm{~g} / \mathrm{m}^{2}$ and the volumetric density of the fabric with a thickness of $4.2 \mathrm{~mm}$ was $112.8 \mathrm{mg} / \mathrm{cm}^{3}$.

The results of the analysis show that the surface density decreased from 459.6 $\mathrm{g} / \mathrm{m}^{2}$ to $355.4 \mathrm{~g} / \mathrm{m}^{2}$, accounting for $29 \%$. The volume density decreased from 135 to 81.7 , which is $40 \%$. A $29 \%$ decrease in surface density resulted in a $40 \%$ decrease in volume density. While surface density takes into account the width and height of the tissue, volume density is an indicator that takes into account the thickness as well as the width and height of the tissue.

Therefore, a decrease in volume density indicates a decrease in raw material consumption. The newly created tire-based knitted blended fabrics can be included in the category of resource-saving fabrics with reduced raw material consumption.

It is known that when the textile structure or yarn composition of a knitwear change, its physical and mechanical properties also change. One of the main features that provide a comfortable environment for consumers when using knitted products is air permeability.

The air permeability coefficient $V\left(\mathrm{sm}^{3} / \mathrm{sm}^{2} \cdot \mathrm{sec}\right)$ is determined by the following formula:

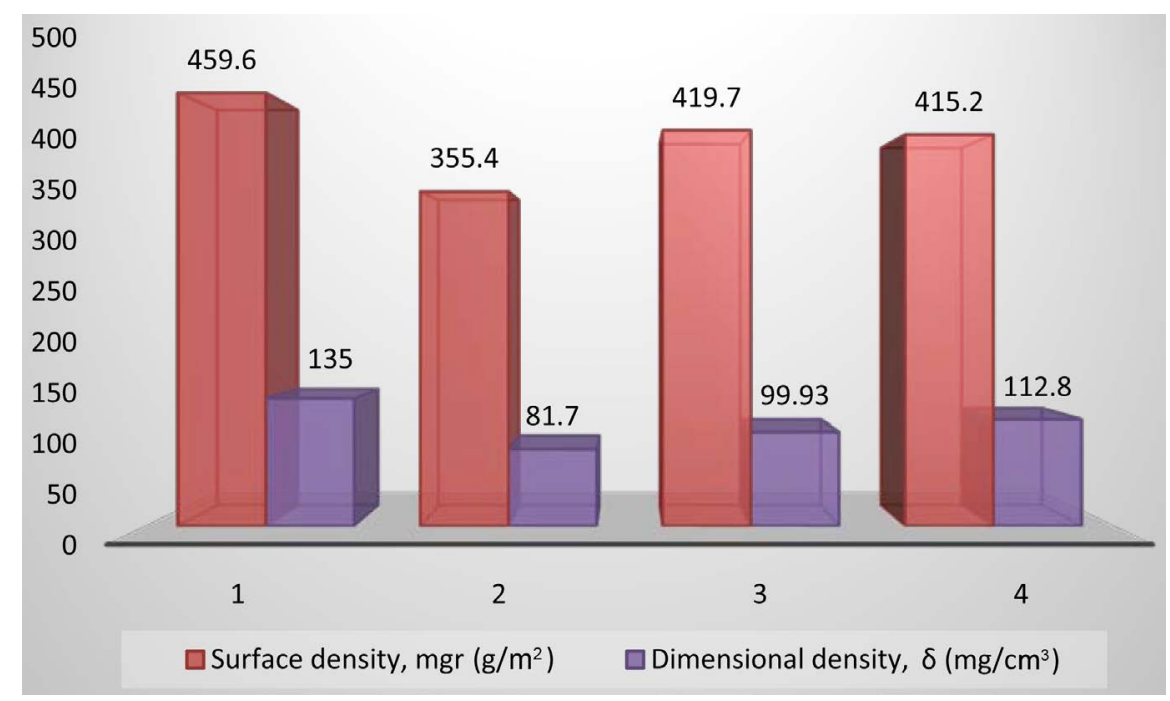

Figure 5. Diagram of tissue surface density and volume density change. 


$$
B=\frac{V}{S \cdot T} \mathrm{sm}^{3} / \mathrm{sm}^{2} \cdot \mathrm{sec} ;
$$

where: $V$ is the amount of air passing through the fabric at a given pressure difference $\Delta \mathrm{P}, \mathrm{cm}^{3}$;

$S$ : fabric area, $\mathrm{sm}^{2}$;

T: the time of passage of air through the fabric, sec.

The base fabric (Table 2) is Version 1, which is a rubber fabric obtained on a two-needle flat fang machine, while Versions 2, 3, 4 are samples of new knitted mixed knitting fabric, which add glad, press and openwork rings to the base of the tire fabric, new options of knitted mixed knit fabric are obtained. The raw material composition of the resulting knitted mixed knitting fabric was the same and was developed using $\mathrm{Nm}=28.6 / 2(35 \times 2$ tex $)$ polyacrylonitrile yarn. The air permeability of the knitted mixed knitting fabric samples under study varied from $31.32 \mathrm{~cm}^{3} / \mathrm{cm}^{2} \cdot \sec$ to $54.36 \mathrm{~cm}^{3} / \mathrm{cm}^{2} \cdot \sec$ (Figure 6).

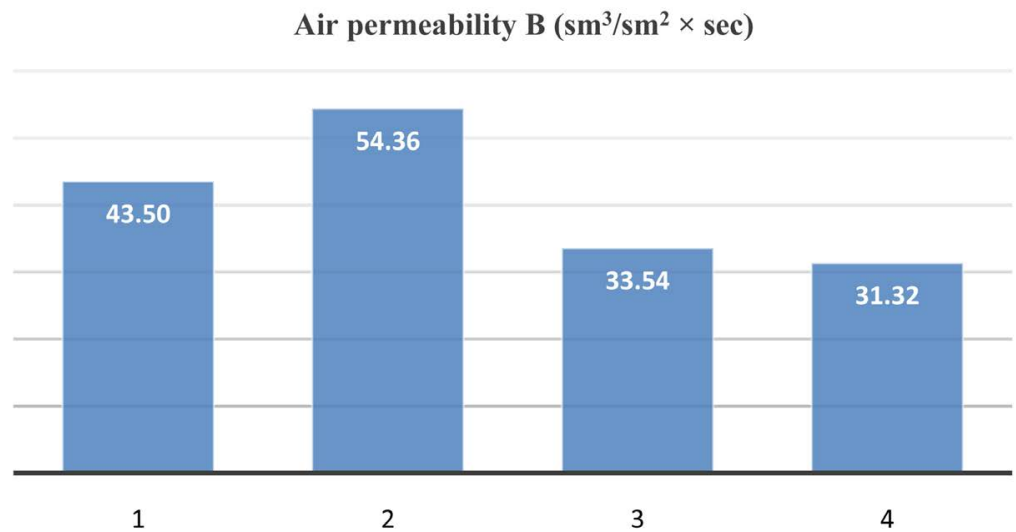

Figure 6. Air permeability histogram of two-layer mixed knitted fabric.

Table 2. Physical and mechanical properties of tissues.

\begin{tabular}{cccccc}
\hline \multirow{2}{*}{ Indicators } & & \multicolumn{4}{c}{ Versions } \\
\cline { 3 - 6 } & & I & II & III & IV \\
\hline \multirow{2}{*}{ Air permeability B (sm3/sm2× sek) } & 43.5 & 54.36 & 33.54 & 31.32 \\
\hline \multirow{2}{*}{ Interruption force R (N) } & In height & 300 & 233 & 177 & 374 \\
& In width & 233 & 243 & 219 & 416 \\
\hline \multirow{2}{*}{ Stretching to break L (\%) } & In height & 56.8 & 35.25 & 25.35 & 52.5 \\
& In width & 63.7 & 94.70 & 53.85 & 48.1 \\
\hline \multirow{2}{*}{ Irreversible deformation $\varepsilon$ H (\%) } & In height & 13.7 & 17.4 & 12 & 16.7 \\
& In width & 17.8 & 13 & 25 & 11 \\
\hline \multirow{2}{*}{ Back deformation $\varepsilon$ o (\%) } & In height & 86.3 & 82.6 & 88 & 83.3 \\
& In width & 82.8 & 87 & 75 & 89 \\
\hline \multirow{2}{*}{ Fabric shrinkage K (\%) } & In height & 2 & 2 & 3 & 1 \\
& In width & 5 & 3 & 1 & 2 \\
\hline Abrasion resistance I (thousandth circle) & 38,300 & 38,384 & 42,668 & 42,564 \\
\hline
\end{tabular}


The lowest air permeability was found in Version 4 of knitted mixed knitwear and its value was $31.32 \mathrm{~cm}^{3} / \mathrm{cm}^{2} / \mathrm{sec}$, and the highest air permeability was found in Version 2 and its value was $54.36 \mathrm{~cm}^{3} / \mathrm{cm}^{2} / \mathrm{sec}$. The air permeability of the knitted mixed knitwear was $20 \%$ higher than the base fabric, and the air permeability of the Version 3 was $43.5 \%$ lower. It was found out that the Version 3 of mixed knitwear with $100 \%$ PAN yarn on the basis of rubber fabric has high heat retention properties.

One of the indicators that characterize the quality of knitwear is its toughness. The toughness feature of knitwear is formed in terms of its tensile strength and elongation to break. All GOST and TSH applicable to knitted fabrics include normative indicators on elongation and tensile strength. Tensile force is the force required to break a specimen at a given size and speed. The breaking force is expressed in Newton units. The tensile strength of the tested knitted samples was determined using the standard method YG-026T dynamometer. Tissue toughness, i.e., analysis of tensile strength, shows that the most mature tissue in height is the Version I, with an index of $544 \mathrm{~N}$, the lowest is the Version III, and its index is $177 \mathrm{~N}$. (Table 2, Figure 7). The sample tissue under study used less force than the base tissue (Version I). The width of the fabric was also observed in Version IV, the tensile strength of the fabric was $416 \mathrm{~N}$, the lowest tensile strength was observed in Version III, its index was $219 \mathrm{~N}$, and the tensile strength of Version IV was $56 \%$ higher than the rubber tissue of Version I. According to the results of the experiments, the strength of the knitted fabric in terms of tensile strength was recorded in Version IV in terms of height and width.

The fibers obtained from polyacrylonitrile are soft and do not damage the skin, less wrinkled, but retain the pleats and curls formed by heat treatment. The fiber has a non-flattening twist and produces less pilling than other synthetic fibers. Washes well with water and dries quickly, has good heat retention properties. Products made of PAN yarn can be washed many times, without losing

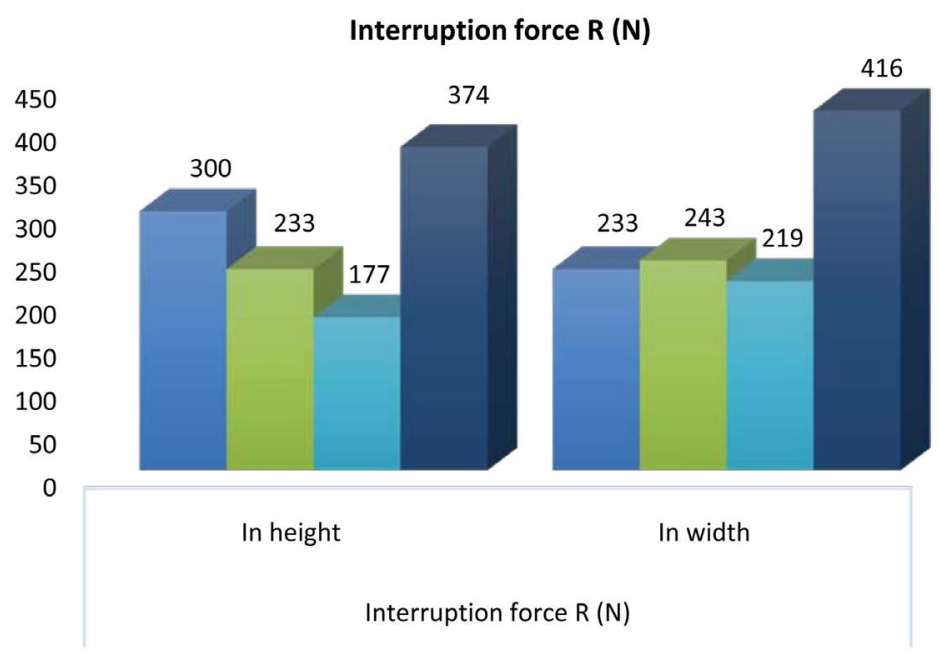

Figure 7. Histogram of change in tensile strength of double-layered mixed knitted fabric. 
their original appearance. Due to the presence of all these properties, PAN yarn can be used in the textile industry in the production of knitwear, in the production of woolen fabrics in combination with other fibers (cotton, silk, wool, viscose).

The composition of the elements in a row of loops and their quantity affect the length of the yarn in the row of rings and thus the elongation property of the knitwear. Elongation is characterized by the elongation of the sample being tested. Elongation is expressed in absolute or relative units (Figure 8). When testing knitted fabrics with a length of $100 \mathrm{~mm}$, clamped to the dynamometer YG-026T, their absolute and relative sizes are the same. The lower the stretch of the fabric, the higher the shape-retaining property of the knitwear. The length elongation of knitted mixed knitwear ranges from $25.35 \%$ to $56.5 \%$. The highest elongation was observed in variant I of the knitted fabric, and it was 56.5\% (Table 2). The elongation along the neck of variant III of the knitted mixed knit fabric was the lowest, which was $25.35 \%$. Patterned mixed knitted fabric was found to be $44 \%$ more elongated (Version III) along the length of Version I.

The elongation across the width of the knitted fabric ranged from $48.1 \%$ to 94.7\%. The maximum width elongation was observed in Version II of the knitwear and it was $94.7 \%$. The minimum width elongation was observed in Version III of the knitted fabric, which was $48.1 \%$.

In summary, the amount of elongation along the length and width of a knit will depend on the structure of the knitted fabric and the type of yarn it contains.

When designing products, it is important to know what elastic properties knitted fabrics have [3].

One of the most important features of knitted products is their shape retention feature. The shape-retaining property of knitwear is characterized by its elongation, reversible and irreversible deformation, and permeability.

The complete deformation $\varepsilon$ consists of the following parts: the flexible part $\varepsilon_{f}$ returns at high speed after 30 minutes after the loads are removed from the samples being tested; elastic deformation $\mathcal{E}_{e}$ develops at a small rate, associated with the passage of the relaxation process; plastic deformation $\varepsilon_{p}$, does not return after removal of loads from samples.

$$
\varepsilon=\varepsilon_{f}+\varepsilon_{e}+\varepsilon_{p}, \%
$$

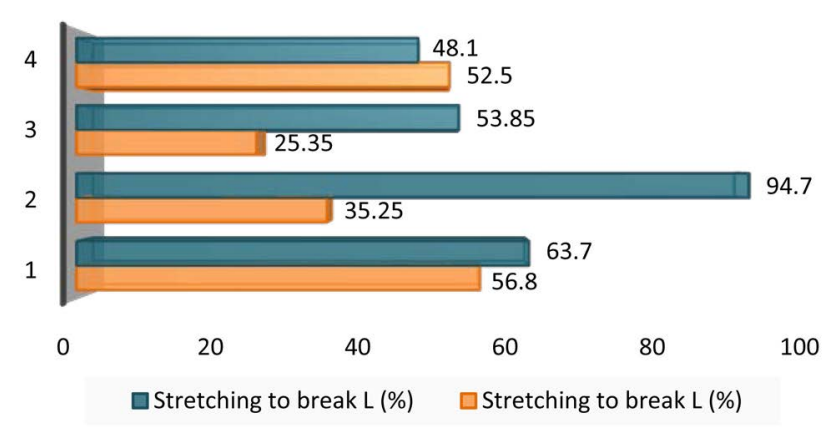

Figure 8. Histogram of change in elongation of two-layer mixed knitted fabric to rupture. 
The deformation of the knit varies with the elasticity, stiffness, and number of loops of the yarn. Not only the description of the deformation, but also the state of the knitting is determined by the internal, two main forces: the elastic force of the yarn bending into the ring tends to straighten the yarn and change its shape. The result is a frictional force between the yarns, which prevents the placement of the yarns in the loop and interferes with the structure of the knitted fabric [4] [5].

The proportion of longitudinal irreversible deformation in high-performance double-layer mixed knitted fabric samples varies from $12 \%$ to $30 \%$, while the proportion of irreversible deformation in width varies from 11\% to $25 \%$ (Table 2, Figure 9).

The proportion of longitudinal irreversible deformation in high-performance double-layer mixed knitted fabric samples varies from $82.6 \%$ to $88 \%$, while the proportion of irreversible deformation in width varies from $75 \%$ to $89 \%$ (Table 2, Figure 10).

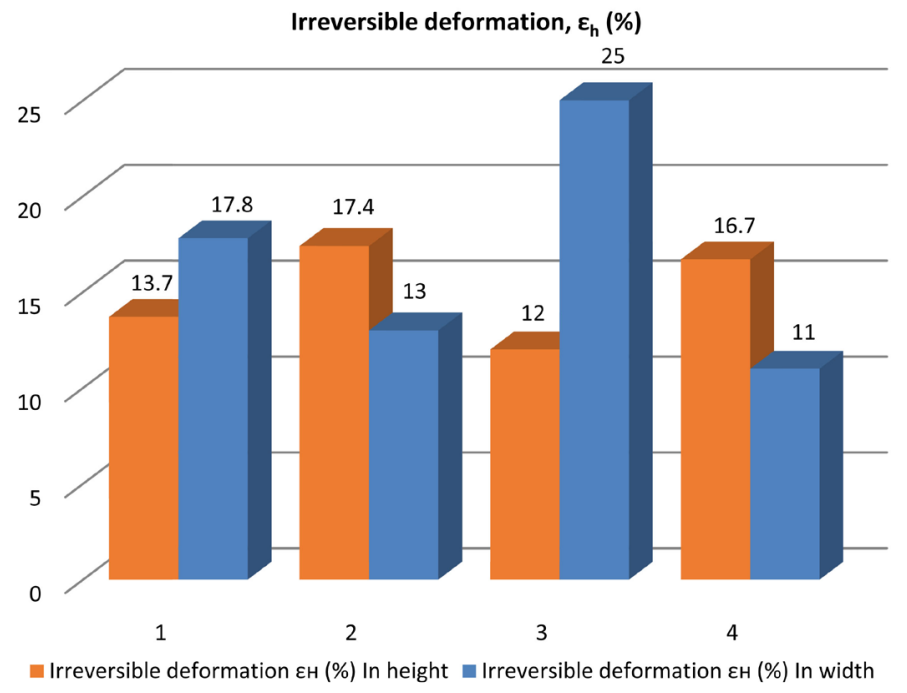

Figure 9. Histogram of the most $\varepsilon_{h}(\%)$ change in irreversible deformation of double-layered mixed knitted fabric.

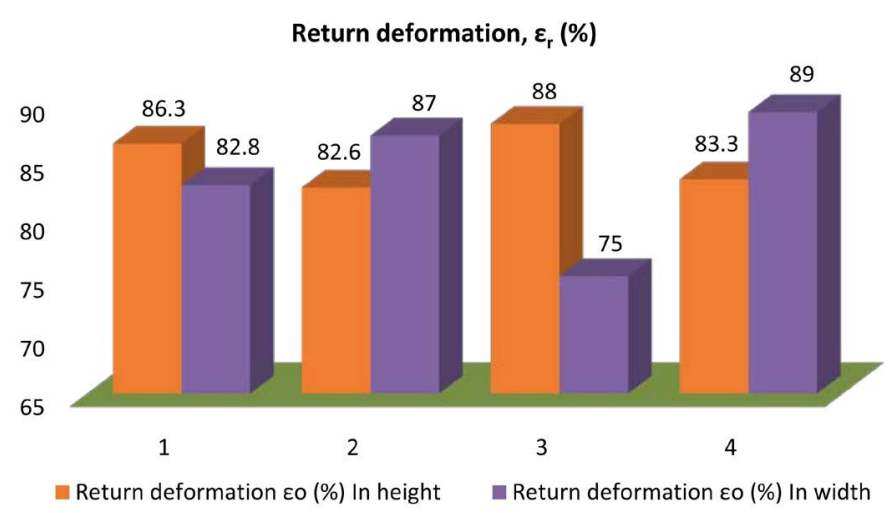

Figure 10. Histogram of $\varepsilon_{o}(\%)$ change in re-deformation of double-layered mixed knitted fabric. 
Such indications of the proportion of back deformation indicate that the patterned mixed knitted fabric quickly returns to its original position after elongation.

Knitting permeability refers to the change in knit size during wet processing. Glad, rubber, press, openwork-based knitted mixed knitted fabrics belong to the group of low penetration in length and width.

When knitted fabrics are processed, the less the knit enters, the higher its shape-retaining properties. Studies have been conducted to study the effect of the amount of polyacrylonitrile yarns in the composition of double-layered mixed knitted fabrics on the permeability properties. The results of the study of the penetration process of double-layered mixed knitted fabric samples showed that the penetration varied from $3 \%$ to $1 \%$ in height and from $5 \%$ to $1 \%$ in width (Table 2, Figure 11).

Knitted fabrics have a significantly higher elongation than woven fabrics and have a highly elastic structure, even under the influence of small stresses. The principle of operation of machines for the finishing of knitted fabrics is almost no different from the machines for the finishing of woven fabrics. It has been noted that one of the main reasons for high penetration is excessive deformation of knitted fabrics in finishing operations. In short, due to the effect on the structure of the knitted mixed knitted fabric obtained on the basis of tires, glad, press, openwork ring pumps, its thickness, heat and shape retention properties increased completely.

During the use of knitted products, the fabric is subject to abrasion when in contact with surrounding objects, and as a result, some parts of the product become unusable. The Versions with the highest abrasion resistance of the knitted mixed knitted fabric obtained on the basis of tires are Versions I and III. Version I friction resistance is 42.5 thousand months. The friction resistance of Version III is 42.6 thousand units found that the friction resistance of VersionI was 1.1\% higher than that of Version II (Table 2, Figure 12).

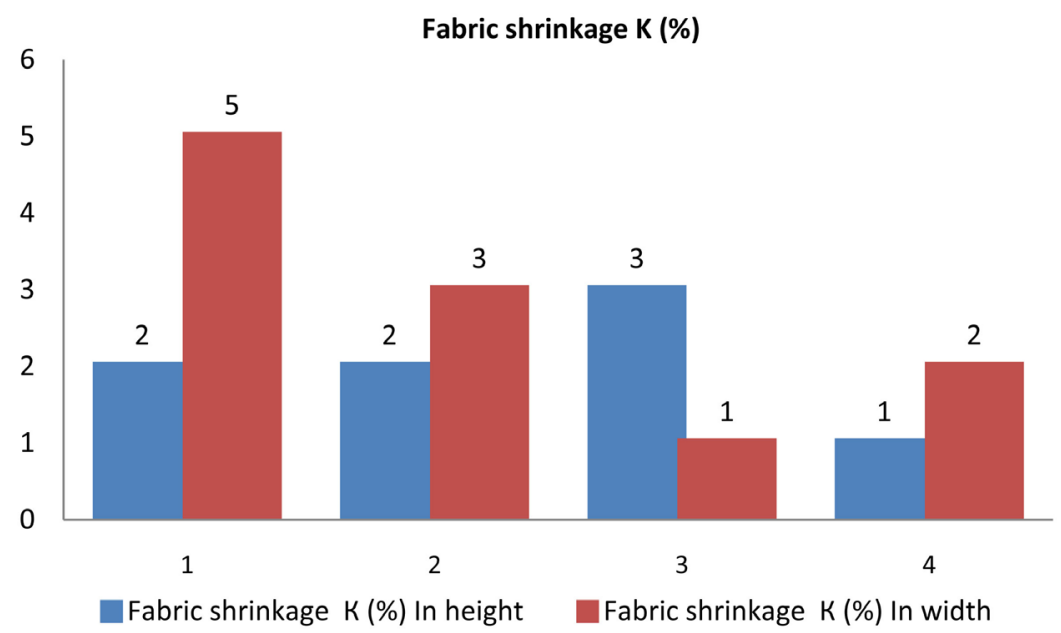

Figure 11. Shrinkage histogram of a two-layer mixed knit fabric. 


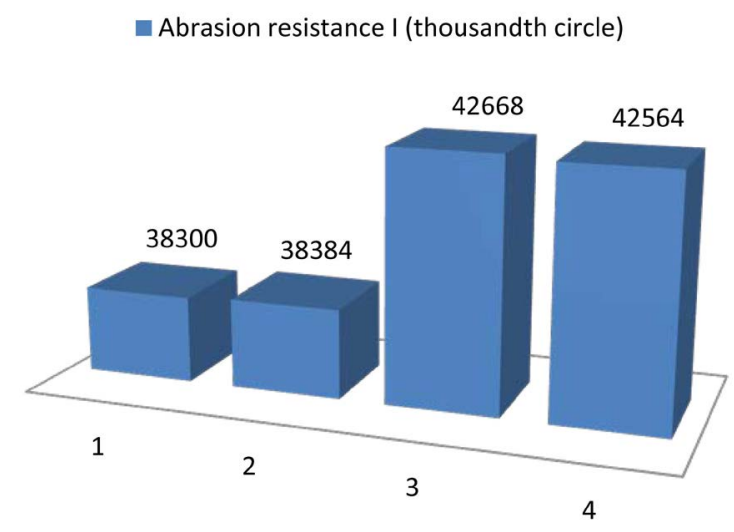

Figure 12. Friction resistance histogram of two-layer mixed knitted fabric.

\section{Conclusions}

From the above analysis of the physical and mechanical properties of knitted mixed knitted fabrics, it is clear that changes in tissue structure, positive effect on the air permeability, toughness, elongation and abrasion resistance properties of knitted fabric strengthen the shape retention of knitted fabric.

The production of knitted fabrics from polyacrylonitrile yarn on the basis of rubber, glad, openwork fabrics allows to obtain knitted products with high hygienic and shape-retaining properties, toughness and beautiful appearance.

In summary, the technological performance of the newly created knitted fabrics has been studied and they are recommended for top knit products.

\section{Conflicts of Interest}

The authors declare no conflicts of interest regarding the publication of this paper.

\section{References}

[1] Shogofurov, Sh.Sh., Kamalova, I.I., Xoliqov, Q.M. and Meliboev, U.X. (2020) Structure and Methods for Producing Refined Two-Layer Knitted Sheets. Solid State Technology, 63, 11798-11807.

http://www.solidstatetechnology.us/index.php/ISST/article/view/6183

[2] Juraboev, A.T., Kholiqov, Q.M. and Shogofurov, Sh.Sh. (2020) The Study of the Technological Parameters of Double Layer Knitwear with Various Methods of Connecting Layers. ACADEMICIA: An International Multidisciplinary Research Journal, 10, 397-404.

https://www.indianjournals.com/ijor.aspx?target=ijor:aca\&volume $=10 \& i s s u e=4 \& a r$ $\underline{\text { ticle }=058}$ https://doi.org/10.5958/2249-7137.2020.00155.X

[3] Kholikov, K.M., Juraboev, A.T., Shogofurov, Sh.Sh. and Abduvaliev, D.M. (2020) Comprehensive Assessment of the Two-Layer Knitwear Quality. The Way of Science, № 1, 24-30.

http://scienceway.ru/f/the way of science no 1 71 january.pdf\#page=24

[4] Sadykova, F.Kh., Sadykova, D.M. and Kudryashova, N.I. (1989) Textile Materials Science and the Basics of Textiles Production. M. Legprombytizdat, 219-225. 
[5] Koblyakov, A.I., Kukin, G.N. and Soloviev, A.N. (1986) Laboratory Workshop on Textile Materials Science. 2nd Edition, M. Legprombytizdat, 232-245.

[6] Mirusmanov, B.F. (2004) Development of Technology for Producing Cotton Silk Linen Jersey. Diss. Cand. Tech. Sciences. T.: TITLP, 140 p.

[7] Kholikov, K.M. and Mukimov, M.M. (2019) Cotton-Silk Knitted Fabric Analysis of Physical and Mechanical Parameters. Scientific and Technical Journal of the Namangan Institute of Engineering Technologies, 4, 41-46. 